\title{
NOTAS SOBRE UM HERMÉTICO "JARDIM" \\ (ou a poesia como mistério programado)
}

\author{
Lino Machado
}

UFES

\begin{abstract}
RESUMO
Discussão do hermetismo do poema "Jardim", de Carlos Drummond de Andrade. Enfoque do texto por meio da estética do Simbolismo.
\end{abstract}

\section{PALAVRAS-CHAVE}

Poesia modernista brasileira, Hermetismo, Carlos

Drummond de Andrade.

\section{Primeiras abordagens de Um poema}

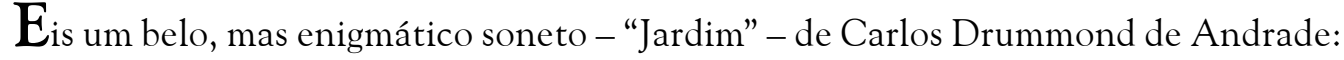

Negro jardim onde violas soam e o mal da vida em ecos se dispersa: à toa uma canção envolve os ramos, como a estátua indecisa se reflete

no lago há longos anos habitado por peixes, não, matéria putrescível, mas por pálidas contas de colares que alguém vai desatando, olhos vazados

e mãos oferecidas e mecânicas, de um vegetal segredo enfeitiçadas, enquanto outras visões se delineiam

e logo se enovelam: mascarada, que sei de sua essência (ou não a tem), jardim apenas, pétalas, presságio.

(ANDRADE, 1973, p. 159)

Tendo em vista o seu relativo hermetismo, aproximemo-nos de tal soneto do modo recomendável em situações semelhantes, ou seja, aos poucos, avançando, com bastante cuidado, dos aspectos mais óbvios aos menos evidentes.

"Jardim" é um dos Novos poemas, livro de Drummond publicado em 1948: um soneto estruturado em versos brancos, quase na sua íntegra. Os únicos pares de rimas em final de verso são: habitADO/vazADOs (quinto e oitavo versos) e enfeitiçADAs/mascarADA 
(décimo e décimo segundo versos). Significativo que o primeiro dos pares de rimas seja formado por duas palavras que podem ser consideradas semanticamente opostas: a idéia de algo habitado pressupõe ocupação, povoamento, etc.; já o sentido de vazar é o de tornar vazio, oco, etc. De um lado, temos: certa presença num determinado espaço; do outro, encontramos: ausências num espaço diverso. No que se refere a tal dupla de termos, a aproximação de significantes denominada rima acha-se, assim, de algum modo, "neutralizada" pelos significados que tais significantes carregam. Essa "neutralização" só vem à mente do leitor porque, como dissemos, o soneto foi, na sua quase totalidade, escrito sem rimas em fim de verso: consideradas as significações de habitado e vazado (o cheio e o vazio), pode-se dizer que, graças a tal jogo antitético, a existência da rima em -ADO não destoa muito, afinal, da inexistência de rimas terminais em boa parte de "Jardim" (e quanto à terminação - ADA, por ser apenas o feminino da rima que discutimos, ela não chega a escapar à "neutralização" aqui proposta).

Na sua dimensão métrica, também quase na sua íntegra, "Jardim" é composto de decassílabos heróicos (como mostra o quadro a seguir, em que a numeração arábica corresponde às sílabas tônicas do poema):

\begin{tabular}{|c|c|}
\hline $\begin{array}{l}1-4-8-10 \\
2-4-6-10 \\
2-6-8-10 \\
3-6-10\end{array}$ & $\begin{array}{l}\text { (decassílabo sáfico) } \\
\text { (decassílabo heróico) } \\
\text { (decassílabo heróico) } \\
\text { (decassílabo heróico) }\end{array}$ \\
\hline $\begin{array}{l}2-4-6-10 \\
2-4-6-10 \\
3-6-10 \\
2-3-6-10\end{array}$ & $\begin{array}{l}\text { (decassílabo heróico) } \\
\text { (decassílabo heróico) } \\
\text { (decassílabo heróico) } \\
\text { (decassílabo heróico) }\end{array}$ \\
\hline $\begin{array}{l}2-6-10 \\
4-6-10 \\
2-6-10\end{array}$ & $\begin{array}{l}\text { (decassílabo heróico) } \\
\text { (decassílabo heróico) } \\
\text { (decassílabo heróico) }\end{array}$ \\
\hline $\begin{array}{l}2-6-10 \\
2-6-10 \\
2-4-6-10\end{array}$ & $\begin{array}{l}\text { (decassílabo heróico) } \\
\text { (decassílabo heróico) } \\
\text { lecassílabo heróico) }\end{array}$ \\
\hline
\end{tabular}

É possível pensar que, no plano do ritmo, a presença maciça do decassílabo heróico (treze versos em quatorze, com tal medida) compense a pouca presença de rimas, no plano fônico (também com óbvia repercussão na esfera rítmica) do poema.

Quanto à dimensão sintática, percebemos que não há pausa discursiva entre uma estrofe e outra, ou seja, os dois quartetos e os dois tercetos acham-se ligados, formando uma única e grande frase, iniciada por "Negro jardim" e terminada por "pétalas, presságio". Em termos técnicos, "Jardim" se vale do velho recurso denominado, na nossa tradição (galego-portuguesa e brasileira), atafinda, típico da lírica dos trovadores, assim explicado por Massaud Moisés: "Processo métrico empregado na poesia trovadoresca, segundo o qual os versos se encadeiam uns nos outros até o fim da cantiga. A vinculação entre os segmentos pode resultar do que hoje se denomina enjambement [...]; ou do uso de conjunções, como $e$, ca [porque], pois, quando, etc." (MOISÉS, 1985, p. 46). Encontram-se, em "Jardim", os dois procedimentos referidos. Exemplo de enjambement: "como a estátua indecisa se reflete 
// no lago há longos anos habitado". Exemplo da utilização de conjunções: "enquanto outras visões se delineiam // e logo se enovelam".

Quanto aos apoios fônicos do texto que não as rimas externas, eis alguns dos mais evidentes a uma primeira leitura:

Verso "no lago há longos anos habitado":

a) aliterações: "LaGo há LonGos anos habitado"

b) assonâncias: "lAgo hÁ longos Anos hAbitAdo"

c) rima imperfeita interna: $1 \mathrm{AgO} /$ habit $\mathrm{AdO}$

Verso "por peixes, não, matéria putrescível":

a) aliterações: "Por Peixes, não, maTéria PuTrescível"

Verso "mas por pálidas contas de colares":

a) aliterações: "páLidas Contas de CoLares"

Verso "jardim apenas, pétalas, presságio":

a) aliterações: "jardim aPenas, Pétalas, Presságio"

b) assonâncias: "jArdim ApEnas, pÉtAlas, prEssÁgio"

Verso "que sei da sua essência (ou não a tem)":

a) aliterações: "Sei da Sua eSSência (ou não a tem)"

b) assonâncias: "quE sEi da sua EssÊENcia (ou não a tEM)":

Agora, eis alguns dos recursos fônicos que podem ser menos perceptíveis a um primeiro exame do texto:

Primeira estrofe: Violas/Vida/enVolVe

Segunda estrofe: Peixes/Putrescível/Pálidas

Segunda e última estrofe envolvidas: "MAS por pÁliDAs"/"MAScAraDA"

Passemos, entretanto, à análise do nível semântico do soneto (não sem antecipar que, na seção final do presente estudo, o mesmo nível será correlacionado aos aspectos métricos, fônicos e sintáticos, assinalados acima).

\section{Abordagem mais arRISCADA - ou A Cena obscura de "JARDim"}

Não rimarei a palavra sono

com a incorrespondente palavra outono.

Rimarei com a palavra carne

ou qualquer outra, que todas me convêm.

Carlos Drummond de Andrade ("Consideração do poema")

De certo modo, o poema "Jardim" se reaproxima da "poética do vago", da "arte da sugestão" da estética do Simbolismo, tal como praticada, sobretudo, por Paul Verlaine e Stéphane Mallarmé, no século XIX. Aliás, isto ocorre já no seu nível semântico: vários autores simbolistas não apenas buscaram aproximar a lírica da música, tentando reproduzir na esfera do significante certos efeitos que encontravam na arte da instrumentação sonora, como ainda tomaram como tema dos seus textos a mesmíssima música - e é o que se passa em "Jardim", conforme adiante veremos. 
Não é estranho que um escritor modernista, como Drummond, se volte para uma tendência artística do passado, como o Simbolismo, pois este foi uma das fontes reconhecidas da Modernidade (cf., por exemplo, FRIEDRICH, 1978, passim).

Em Verso universo em Carlos Drummond de Andrade, José Guilherme Merquior dedicou quatro páginas à análise de "Jardim" (MERQUIOR, 1976, p. 145-148). Brilhante, tal interpretação é efetuada a partir de uma perspectiva estilística que privilegia, no poema, o plano fônico, principalmente, e o sintático, em parte. Merquior não deixa de acusar "certo hermetismo" em "Jardim", tratando-o também como "poema esotérico", de um "lirismo secreto" (MERQUIOR, 1976, p. 145, 148 e 149). Supomos que o estudioso tem razão nas suas ponderações; todavia, insistimos em aproximar "Jardim" do Simbolismo. Em "Poesia e sugestão", Mallarmé assim se refere ao seu métier:

Penso ser preciso [...] que haja somente alusão. [...] Nomear um objeto é suprimir três quartos do prazer do poema, que consiste em ir adivinhando pouco a pouco: sugerir, eis o sonho. É a perfeita utilização desse mistério que constitui o símbolo: evocar pouco a pouco um objeto para mostrar um estado d'alma, ou inversamente, escolher um objeto e extrair dele um estado d'alma, através de uma série de decifrações. (Apud GOMES, 1985, p. 98)

Em "A música e as letras", o poeta francês afirma: "Arcando esteticamente com as conseqüências, apresento esta conclusão [...]: que a Música e as Letras são a face alternativa aqui ampliada na direção do obscuro" (apud GOMES, 1985, p. 102).

Em "Jardim", Drummond pratica, de modo moderado, tal estética do "obscuro". Acreditamos, porém, que, como frisado pelo próprio Mallarmé, o leitor consegue "ir adivinhando pouco a pouco" alguma coisa de importante no que é sugerido na composição. Isto no terreno semântico, do qual procuraremos fazer uma paráfrase (necessária, por causa da dificuldade de entendimento do que é dito no texto), a que acrescentaremos uma interpretação mais desenvolvida, ainda que, inevitavelmente, arriscada.

Se, num jardim, "violas soam" e certa "canção envolve os ramos" (temática simbolista), parece ali ocorrer algo de natureza coletiva: talvez alguma espécie de festa, como o vocábulo mascarada sugere. Um dos significados de tal termo é: Festa de que tomam parte pessoas mascaradas, baile de máscaras.

Uma festa é um evento que, por natureza, não pode ter uma duração muito extensa. $\mathrm{Na}$ segunda estrofe do soneto vem dito que o lago do jardim é "há longos anos habitado / [...] por pálidas contas de colares / que alguém vai desatando". Se as "contas de colares" são jogadas na água por "alguém”, tal pessoa deve ser uma mulher, pois as jóias em questão, na nossa cultura (e no ano da publicação de "Jardim": 1948), são utilizadas por mulheres, não por homens. Essas jóias, claro, são típicas do aparato mais ou menos codificado da elegância feminina. Ora, se alguma mulher, ao longo dos anos (e não apenas da suposta cena festiva que se vislumbra em "Jardim", necessariamente curta), lança no lago as contas não do seu colar, mas dos seus colares (e note-se aqui a importância do plural, que, junto com a palavra anos, enfatiza a constância do ato feminino), isto indica certa frustração na sua existência (na primeira estrofe fala-se no "mal da vida"): o fato de serem descartados apetrechos tão importantes da vaidade feminina induz-nos a pensar que tal vaidade foi ferida em algum ponto essencial (talvez no que a mesma vaidade heterossexualmente almeja: a sedução de um homem). Esse ponto essencial o poema, de propósito, não elucida, como 
indica o único verso que contém marca da primeira pessoa: "que sei da sua essência (ou não a tem)". A "essência" do segredo nem é esclarecida nem é negada (note-se que o trecho entre parênteses do verso por fim citado começa por um ou, uma conjunção alternativa que nos deixa entre duas opções, sem elementos para escolher entre qualquer uma delas).

A hipótese de uma frustração amorosa é reforçada pela terceira estrofe do soneto: "e mãos oferecidas e mecânicas / de um vegetal segredo enfeitiçadas, / enquanto outras visões se delineiam”. O “vegetal segredo", que ainda encanta as mãos, bem pode ser o de uma cena amorosa (ousada ou não) em meio à natureza, tema de inúmeras obras no transcorrer dos séculos, as quais não são apenas de caráter literário. No que se refere à literatura, basta lembrar a tradição bucólica, que, vinda mais claramente dos gregos, chega aos nossos dias.

Um jardim combina elementos do mundo natural com elementos do cultural. $\mathrm{O}$ primeiro livro de versos de Drummond, Alguma poesia, traz um poema intitulado "Iniciação amorosa”. Esta se dá num cenário bucólico que mistura dados naturais (mangueiras) com um detalhe cultural (rede):

A rede entre duas mangueiras balançava no mundo profundo. $[\ldots]$

E como eu não tinha nada que fazer vivia namorando as pernas da lavadeira.

Um dia ela veio para a rede, se enroscou nos meus braços, me deu um abraço, me deu as maminhas que eram só minhas. A rede virou, o mundo afundou. (ANDRADE, 1973, p. 22)

Eis, acima, um texto cuja cena amorosa é bem mais explícita (mais ligada, portanto, à "palavra carne", para nos servimos de parte de um dos versos de "Consideração do poema") do que a cena possivelmente também amorosa de "Jardim", a qual, caso exista (como pensamos) de modo implícito no poema, parece culminar numa decepção feminina. A última palavra de "Jardim" é "presságio". Mas, tanto para o eu que se insinua no penúltimo verso, quanto para nós, leitores, "presságio" de quê? Uma coisa é certa: de nada que haja terminado (ou que ainda venha a terminar) com um desfecho feliz. A "mascarada", vocábulo que igualmente pode referir-se a uma mulher, não apresenta um sigilo que se desvele aos olhos do leitor; porém, algo persiste: "um vegetal segredo", envolvendo plantas, uma provável figura feminina, um ato desta, incomum, que se assemelha a um gesto de despeito, recorrente ao longo dos anos, como uma espécie de "neurose de repetição", motivada por alguma castração amorosa. 


\section{O PLANO DO SIGNIFICANTE E O DO SIGNIFICADO VISTOS CONJUNTAMENTE}

Dissemos mais acima ser possível pensar que, na dimensão do ritmo, a presença avassaladora do decassílabo heróico (assinalável em treze versos do soneto) compensa a escassa presença de rimas, no terreno fônico de "Jardim". Também equilibra a pouca incidência das mesmas a quantidade considerável de apoios fônicos no poema. Tais contrabalanceamentos, porém, não eliminam o fato de que inexiste uma seqüência rimática maior no texto - inexistência que gostaríamos de correlacionar a uma segunda, igualmente assinalada: a de pausa sintática entre as estrofes da composição.

Ora, um soneto que, de um lado, não contém um número relevante de rimas em final de verso e, de outro, flui sem interrupção discursiva da sua primeira à sua última palavra exige de nós, em princípio, uma leitura muito mais atenta do que a pedida por um soneto de recorte mais tradicional (ou seja, rimado e com pontuação interna). Essas duas grandes ausências em "Jardim", ligadas ao plano do significante (ou da expressão), articulamse, segundo pensamos, à obscuridade intencional do texto, localizada no plano do significado (ou do conteúdo), do seguinte modo: a maior atenção de leitura exigida pela dimensão mais formal de "Jardim" tem correspondência, por assim dizer, na necessidade de leitura muito aplicada ao que é dito, de maneira deliberadamente misteriosa, nos seus versos (e também se deve afirmar o contrário: a semântica da composição por igual se "espelha" nas suas dimensões fônica e sintática).

Sendo "Jardim" um belo poema, não é de estranhar, nele, a presença de inter-relações da espécie que apontamos. Um dos estudiosos da arte da poesia sintetizou assim o que nesta ocorre: "o discurso poético é na realidade um discurso duplo que projeta as suas articulações simultaneamente nos dois planos - no da expressão e no do conteúdo" (GREIMAS, 1975, p. 12). Tratando-se de um autor da estatura de Carlos Drummond de Andrade, nada há a estranhar quando se percebe tal "duplicidade" em "Jardim", sem dúvida, mas existe muito a admirar: uma coisa é estudar o processo, outra, bem diversa, deflagrálo. A obviedade deste raciocínio não tem correspondência, infelizmente, nas dificuldades inerentes à prática para a qual ele aponta.

\section{A}

\section{A B STRACT}

A discussion of hermeticism in the poem "Jardim", by Carlos Drummond de Andrade, undertaken in terms of Symbolist aesthetics.

\section{KEYWORDS}

Brazilian Modernist Poetry, Hermeticism, Carlos Drummond de Andrade. 


\section{REFERÊNCIAS BIBLIOGRÁFICAS}

ANDRADE, Carlos Drummond. Reunião: dez livros de poesia. 3. ed. Rio de Janeiro: José Olympio, 1978.

BUARQUE DE HOLANDA, Aurélio. Novo dicionário da língua portuguesa. 1. ed. 14. impr. Rio de Janeiro: Nova Fronteira, 1975.

FRIEDRICH, Hugo. Estrutura da lírica moderna: da metade do século XIX a meados do século XX. Trad. Marise M. Curioni e Dora F. da Silva. São Paulo: Duas Cidades, 1978.

GOMES, Álvaro Cardoso. A estética simbolista: seleção de textos, comentários, introdução geral, bibliografia e índice de nomes. São Paulo: Cultrix, 1984.

GREIMAS, A. J. (Org.) Ensaios de semiótica poética. Trad. Heloysa Lima Dantas. São Paulo: Cultrix/Ed. da USP, 1975.

MERQUIOR, José Guilherme. Verso universo em Drummond. Trad. Marly de Oliveira. 2. ed. Rio de Janeiro: José Olympio, 1976, p. 145-148.

MOISÉS, Massaud. Dicionário de termos literários. 4. ed. São Paulo: Cultrix, 1985. 